\title{
Genetic and genomic analysis of long insemination interval in Israeli dairy cattle as an indicator of early abortions
}

\author{
Moran Gershoni, ${ }^{1}$ () Ephraim Ezra, ${ }^{2}$ and Joel Ira Weller ${ }^{1,2 *}$ (1) \\ ${ }^{1}$ Department of Ruminant Science, Institute of Animal Sciences, Agricultural Research Organization, the Volcani Center, Rishon LeZion 7505101, \\ Israel \\ ${ }^{2}$ Israeli Cattle Breeders Association, Caesarea Industrial Park 3088900, Israel
}

\begin{abstract}
One of the causes of observed low fertility is embryo loss after fertilization. Previous findings suggested that more than half of fertilizations result in embryo loss before pregnancy is detected. We proposed reinsemination between 49 and $100 \mathrm{~d}$ after the first insemination as an indicator trait for early abortion (EA) in dairy cattle based on the mean estrus interval of $21 \mathrm{~d}$. This trait was compared with conception rate from first insemination and conception status, computed as the inverse of the number of inseminations to conception. Animal model variance components were estimated by REML, including parents and grandparents of cows with records. First-parity heritability for first insemination conception rate was $3 \%$. In the multitrait analysis of parities 1 to 3 for putative EA, heritabilities ranged from $8.9 \%$ for first parity to $10.4 \%$ for second parity. All genetic correlations were $>0.9$, whereas all environmental correlations were $<0.12$. The variance component for the service sire effect for putative EA rate was less than half the variance component for conception rate. Thus, genetic control of the 2 traits is clearly different, and analysis of EA rate by a single-trait animal model is justified. Genetic evaluation for putative EA was computed using this model, including all first- through third-parity cows with freshening dates from January 1 , 1985, through December 31, 2016, that either became pregnant on first insemination or were reinseminated between 49 and $100 \mathrm{~d}$ after the first insemination. All known parents and grandparents of cows with records were included in the analysis. The regression of the breeding value for non-abortion rate on the cows' birth year was $0.083 \% / \mathrm{yr}$. The genetic correlation between first-parity EA and conception status was 0.995. The genetic correlations between first-parity EA and milk,
\end{abstract}

Received August 21, 2019.

Accepted December 18, 2019.

*Corresponding author: joel.weller@mail.huji.ac.il fat, and protein production were all negative, whereas the genetic correlation between EA and herd life was 0.33 . Inclusion of putative EA in the selection index instead of conception status resulted in 10 to $20 \%$ greater genetic gain for both fertility traits. In a genome-wide association study based on 1,200 dairy bulls with reliabilities $>50 \%$ for abortion rate genotyped for 41,000 markers, 6 markers were found with nominal probabilities of $<10^{-12}$ to reject the null hypothesis of no effect on EA rate. The markers with the lowest probabilities for EA rate were also included among the markers with the lowest probabilities for female fertility, but not vice versa. The marker explaining the most variance for abortion rate is located within the $A B C A 9$ gene, which is found within an ATP-binding cassette (ABC) genes cluster. The ABC family is the major class of primary active transporters in the placenta.

Key words: early abortion rate, conception rate, genome-wide association study, dairy cattle

\section{INTRODUCTION}

Like almost all economic traits in dairy cattle, genetic evaluation of fertility is based on field records. Unlike milk production traits and somatic cell concentration, there is no accepted consensus on how fertility should be scored. Traditionally, the most common criterion was nonreturn rate, the fraction of cows that were not reinseminated within a specific time interval. This criterion ignored cows that were culled after the first insemination (Weller, 1989). More recent measures have considered the time lapse from first insemination to pregnancy or some function of the number of times a cow is inseminated during the lactation (Fleming et al., 2019). Heritabilities for almost all measures of female fertility are in the range of 1 to $4 \%$ (VanRaden et al., 2004; Fleming et al., 2019).

Fertility data in Israel are unique in that cows that are not reinseminated within $60 \mathrm{~d}$ are checked for pregnancy by a veterinarian (Weller, 1989). Although abortions are recorded in Israel, very few first-trimester abortions 
are noted by either the herd manager or the attending veterinarian. Indeed, previous studies in other populations estimated fertilization rate as greater than $75 \%$, whereas the conception rate was approximately $35 \%$ (Santos et al., 2004). The differences between these 2 observations are likely due to pregnancy loss that occurs in approximately $50 \%$ of effective inseminations.

Since genotyping of large numbers of animals with high-density SNP chips has become routine, several recessive lethal alleles have been detected in commercial dairy cattle populations that result in early-term abortions (Cole et al., 2016). Detection was originally based on the lack of homozygotes for the haplotype harboring the lethal allele and a reduction in fertility rate for daughters of sires that received this haplotype. In several cases, the causative polymorphism has been determined (e.g., Schütz et al., 2016). Because the abortion is generally not observed, pregnancies that result in fetuses homozygous for the lethal alleles are recorded as "nonconception."

Many studies have shown that the average estrus interval in dairy cattle is $21 \mathrm{~d}$ (Remnant et al., 2018). Thus, most cows that do not conceive in the first service should be reinseminated approximately $21 \mathrm{~d}$ later. The number of days between first and second insemination for first parity was previously shown to peak at $21 \mathrm{~d}$, with a secondary peak around $42 \mathrm{~d}$, which corresponds to 2 estrous cycles. Despite these 2 prominent peaks, a significant number of cows were reinseminated at $>45$ d after the first insemination (Greenham et al., 2019). These late inseminations may be due to non-conception at the first insemination and lack of observed estrus at the expected interval; another explanation is conception at the first insemination and early-term abortion due to embryonic lethality or female factors increasing the predisposition for embryonic death. One way to test this hypothesis is to demonstrate that the genetic factors that control long intervals between first and second inseminations are different from the genetic factors that control conception and to evaluate the genetic contributions of the cow and the service sire.

Previous studies in humans have suggested that the chance of a woman achieving a successful pregnancy per menstrual cycle is approximately 25\% (Henry, 1965; Sheps, 1965). Among other causes, the lack of detected pregnancy was shown to be the result of early abortion (EA). Approximately $70 \%$ of human conceptions fail to achieve viability, with almost $50 \%$ of all pregnancies ending in miscarriage before the clinical recognition of a missed period or the presence of embryonal heart activity (Edmonds et al., 1982; Carthy et al., 2015). This complicates the study of EA in humans, although it is likely to have a large effect on human fertility.
Cattle share similarities with female reproductive traits, including a similar reproductive cycle (Evans, 2003), ovarian function (Yapura et al., 2011), effects of aging on fertility (Malhi et al., 2005), embryo-maternal communication (Bauersachs et al., 2008; Østrup et al., 2011), pregnancy maintenance, and response to assisted reproduction techniques (Bauersachs et al., 2009; Mansouri-Attia et al., 2009). However, contrary to human, the extensive documentation in many commercial cattle populations, including estrus and insemination records, provides a good opportunity to investigate the genetics of EA. In addition, each ejaculation is evaluated by AI labs, and defective semen is rejected. Thus, the service sire has only a very minor effect on conception rate (Weller and Ron, 1992). The available measurements of progesterone and pregnancy-specific protein B levels from blood and milk enable early assessment of reproductive status in dairy cows (Sasser, 1986; Friggens et al., 2008). These measurements suggested that up to $40 \%$ of all inseminations result in EA (Humblot, 2001). The objectives of this study were (1) to perform genetic and genomic analysis of cows with long intervals between first and second insemination compared with cows recorded as conceiving at first insemination and (2) to compare this trait with 2 different female fertility traits.

\section{MATERIALS AND METHODS}

\section{Data Sets Analyzed}

Nine data sets were analyzed. A basic description of the data sets is given in Table 1, and the numbers of animals and levels of effects included in each data set are given in Table 2. The first data set included first insemination conception rate (FCR) of first-parity Israeli-Holstein cows with calving dates from January 1, 2007, through December 31, 2016, and at least 1 insemination. To define what should be considered a "long interval" between inseminations as indicative of $\mathrm{EA}$, we analyzed the distribution of the insemination interval in Israeli-Holstein cows that were inseminated more than once (Figure 1). Data set 2 included records for putative EA (PEA) for the same time period. Data set 3 was also a subset of data set 1 but was constructed to eliminate cows with PEA. Data sets 4 and 5 were also constructed to analyze PEA but included parities 1 through 3. Data set 4 included the same time limits as the previous data sets, whereas data set 5 included all valid records since 1985 . The trait analyzed in data set 6 was conception status (CS), scored as the inverse of the number of inseminations to conception in percent. For cows that were culled before conception, 
Table 1. Basic description of the 7 data sets analyzed

\begin{tabular}{lllll}
\hline & & & & \multicolumn{2}{c}{ Freshening years included } \\
\cline { 3 - 4 } $\begin{array}{l}\text { Data } \\
\text { set }\end{array}$ & Trait analyzed & $\begin{array}{l}\text { Analysis } \\
\text { type }\end{array}$ & Parities & Beginning \\
\hline 1 & First insemination conception rate, all inseminated cows & VC & 1 & 2007 \\
2 & Putative non-abortion rate & VC & 1 & 2007 \\
3 & First insemination conception rate without abortions & VC & 1 & 2007 \\
4 & Putative non-abortion rate & VC & $1-3$ & 2007 \\
5 & Putative non-abortion rate & SAM & $1-3$ & 1985 \\
6 & Inverse of the number of inseminations to conception & VC & $1-5$ & 1985 \\
7 & Putative non-abortion rate and 9 Israeli index traits & 1 & 2016 \\
8 & Putative non-abortion rate & GWAS & $1-3$ & 1985 \\
9 & Inverse of the number of inseminations to conception & GWAS & $1-5$ & 1985 \\
\hline
\end{tabular}

${ }^{1} \mathrm{VC}=\mathrm{REML}$ variance component analysis based on the animal model; SAM = single-trait animal model with variance components assumed known; MAM = multitrait animal model with variance components assumed known; GWAS = genome-wide association study.

${ }^{2}$ The traits included in the Israeli breeding index (PD16) are given in Table 6.

the expected number of inseminations to conception was computed as described by Weller and Ezra (1997). Data set 7 included first-parity records for PEA and the 9 traits included in the Israeli breeding index (PD16) for cows born between 2008 and 2014. The last 2 data sets included bulls with genotypes and genetic evaluations with reliabilities $>0.05$ for PEA (data set 8 ) and CS (data set 9).

Conception from the first insemination was determined as described previously (Weller, 1989). Briefly, conception was determined by veterinary pregnancy check approximately $60 \mathrm{~d}$ after conception. If there was no record of a pregnancy check, then conception was assumed to have occurred for the insemination that resulted in a gestation length between 265 and $290 \mathrm{~d}$, as determined by parturition following the lactation. If there was no veterinary check and the cow was culled before parturition, then non-conception was assumed if the cow was reinseminated before culling. Otherwise, conception was considered not determined.
The following records were deleted:

1. Cows that were daughters of foreign bulls, due to possible preferential treatment.

2. Cows with first insemination by foreign bulls, also due to possible preferential treatment.

3. Cows with first insemination $\leq 30$ and $\geq 135 \mathrm{~d}$ after parturition.

4. Cows for which pregnancy could not be determined for the first insemination.

The second data set was a subset of the first set and included all cows that were either (1) recorded as pregnant on the first insemination and with pregnancy length $\leq 290 \mathrm{~d}$ or (2) recorded as open on the first insemination and reinseminated between 49 and 100 $\mathrm{d}$ after the first insemination. The latter group was assumed to represent cows with PEA and were given a score of 0 for PEA. All other cows included in this data set were scored as 100 for PEA. Thus, both FCR and

Table 2. Number of animals with records, ancestors, and levels of effects in the analysis models

\begin{tabular}{|c|c|c|c|c|c|c|c|}
\hline Data set $^{1}$ & Parities & $\begin{array}{l}\text { Insemination } \\
\text { month }\end{array}$ & $\begin{array}{l}\text { Service } \\
\text { sire }\end{array}$ & $\begin{array}{l}\text { Herd-year- } \\
\text { seasons }\end{array}$ & $\begin{array}{c}\text { Genetic } \\
\text { groups }\end{array}$ & $\begin{array}{c}\text { Animals } \\
\text { with records }\end{array}$ & Ancestors \\
\hline 1 & 1 & 12 & 569 & 13,699 & 2 & 260,782 & 142,297 \\
\hline 2 & 1 & 12 & 554 & 12,802 & 2 & 118,039 & 123,600 \\
\hline \multirow[t]{3}{*}{4} & $1-3$ & 12 & - & 13,551 & 2 & 182,758 & 136,187 \\
\hline & 1 & 12 & 554 & - & - & 118,039 & - \\
\hline & 2 & 12 & 542 & - & - & 77,193 & - \\
\hline 6 & $1-5$ & - & - & 50,536 & 80 & 861,939 & 143,649 \\
\hline 7 & 1 & - & - & 8,219 & 2 & 83,521 & 101,904 \\
\hline 8 & $1-3$ & - & - & - & - & 1,179 & - \\
\hline 9 & $1-5$ & - & - & - & - & 1,297 & - \\
\hline
\end{tabular}

${ }^{1}$ Data sets are defined in Table 1. 


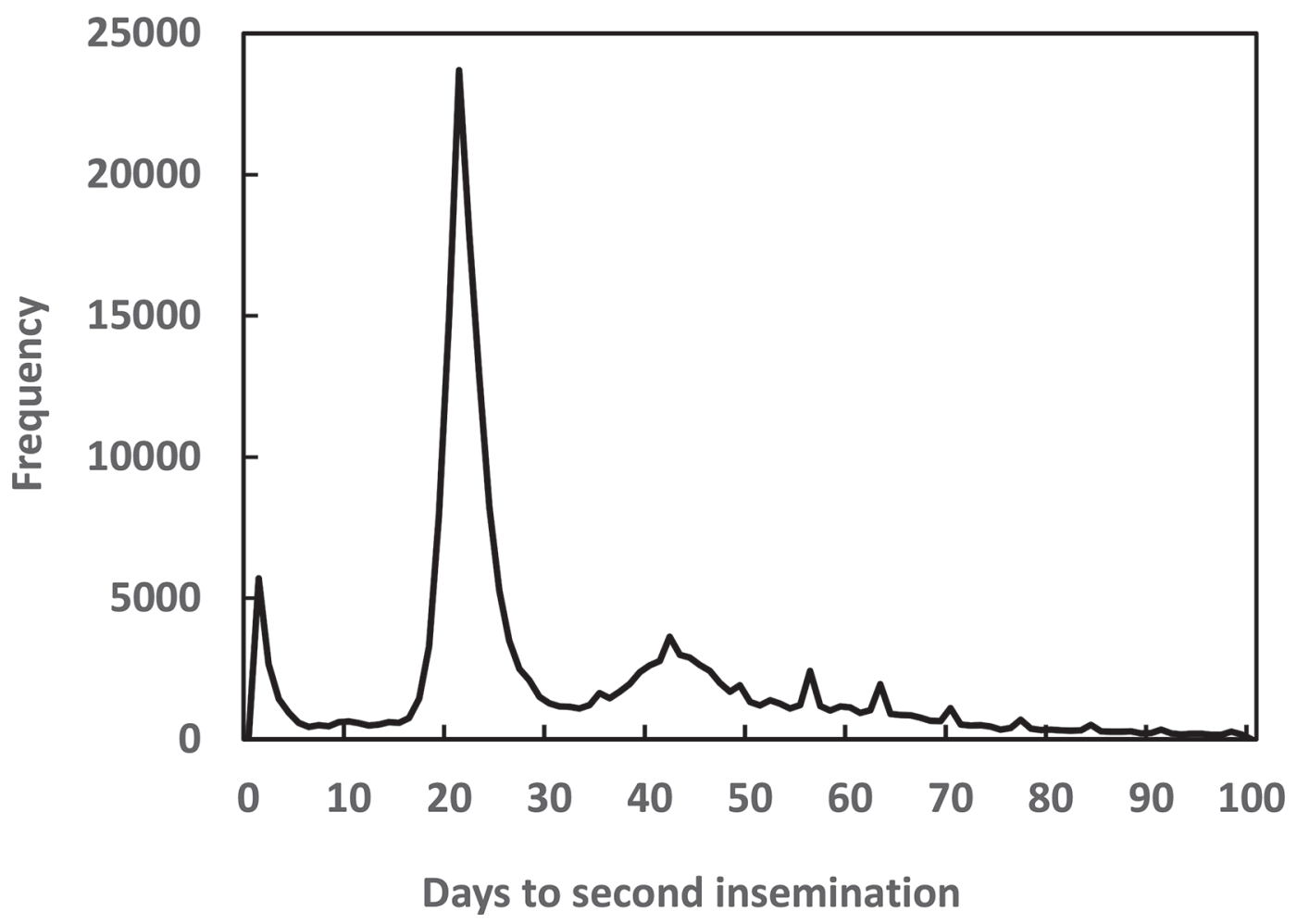

Figure 1. Frequencies of days between first and second inseminations for first-parity Israeli Holstein cows. Valid records of cows freshening between 2007 and 2016 are included.

PEA were scored dichotomously, with non-conception or putative abortion scored as zero and pregnancy scored as 100. Determination of PEA did not require subsequent calving.

The third data set included all cows in the first data set recorded as pregnant on the first insemination or cows that were recorded as open and reinseminated before $49 \mathrm{~d}$ after the first insemination. This data set was assumed to represent cows that either became pregnant or remained open after the first insemination. Although the objective was to eliminate cows with PEA, the latter group of cows clearly included a small fraction of cows that aborted and still displayed estrus before $49 \mathrm{~d}$ after the first insemination.

Cows were included in the fourth data set based on the same criteria as the second data set, but cows in second and third parities were also included. Because cows with second inseminations $<49$ or $>100$ d after first insemination were deleted for each parity, some cows had records on 1, 2, or 3 parities, and for any specific parity a record could be included or deleted. Variance components were computed for all 4 data sets for a binary trait. The analyses included all parents and grandparents of cows with valid records.

Due to computing limitations, REML variance component analyses could be computed only on a subset of the entire herd-book data. To obtain EBV for all bulls and to estimate genetic trends, programs were written that computed BLUP based on assumed values for the variance components. The fifth data set was similar to the fourth data set except that it included all first- through third-parity cows with freshening dates from January 1, 1985, through December 31, 2016, that either became pregnant on first insemination or were reinseminated between 49 and $100 \mathrm{~d}$ after the first insemination. This data set also included cows that were daughters of foreign bulls and even bulls of breeds other than Holsteins, although these cows were only about $1 \%$ of all the cows. This data set was analyzed using the individual animal model to compute genetic evaluations for all bulls with genotypes for medium- or high-density SNP chips. As in the previous data sets, the animal model analysis included all parents and grandparents of cows with valid records.

The sixth data set included valid first- through fifth-parity records for CS with freshening dated from January 1, 1985, through May 31, 2018. All first-parity cows that were inseminated at least once were included. Later-parity cows were included if there were valid records for all previous parities. As in data set 5, cows that were daughters of foreign Holstein bulls and bulls from breeds other than Holsteins were included, and 
Table 3. Index coefficients for the current Israeli breeding index (PD16) and expected gains after $10 \mathrm{yr}$ of selection with this index and an alternative index including putative abortion rate instead of conception status

\begin{tabular}{|c|c|c|c|c|}
\hline \multirow[b]{2}{*}{ Trait } & \multicolumn{2}{|c|}{ PD16 } & \multicolumn{2}{|c|}{ Alternative index } \\
\hline & Coefficient & $\begin{array}{l}\text { Expected } \\
\text { gain }\end{array}$ & Coefficient & $\begin{array}{l}\text { Expected } \\
\text { gain }\end{array}$ \\
\hline Milk (kg) & 0 & 964 & 0 & 956 \\
\hline Fat $(\mathrm{kg})$ & 8.48 & 40 & 8.48 & 40 \\
\hline Protein $(\mathrm{kg})$ & 21.2 & 31 & 21.2 & 31 \\
\hline $\operatorname{SCS}^{1}$ & -300 & -0.034 & -300 & -0.033 \\
\hline Conception status ${ }^{2}(\%)$ & 26 & 0.08 & 0 & 0.10 \\
\hline Herd life $(d)$ & 0.6 & 92 & 0.6 & 91 \\
\hline Persistency (\%) & 10 & 2.8 & 10 & 2.7 \\
\hline Dystocia, maternal $^{1}(\%)$ & -3 & -1.55 & -3 & -1.46 \\
\hline Stillbirth, maternal ${ }^{1}(\%)$ & -6 & -0.10 & -6 & -0.07 \\
\hline Putative abortion rate $^{2}(\%)$ & 0 & 0.65 & 20 & 0.71 \\
\hline
\end{tabular}

the data set included all parents and grandparents of cows with valid records. This data set was analyzed using the multitrait animal model, with each parity considered a separate trait, as described by Weller and Ezra (2004). The separate parity evaluations were combined into a multiparity index based on the economic value of each parity.

Data set 7 included cows born between January 1, 2008, and December 31, 2014, with valid records for PEA and the 9 traits included in PD16. These traits are listed in Table 3. This data set was analyzed using the single-trait animal model to estimate genetic and environmental correlations of the index traits with PEA. As required by this program, only cows with valid records for all 10 traits could be included in the analysis.

The eighth data set included all bulls with genetic evaluations from the analysis of the fifth data set with reliabilities $>50 \%$ and genotypes for one of the medium- or high-density SNP chips. This data set was used to compute the GWAS analysis for frequency of PEA. The final data set included all bulls with genetic evaluations from the sixth data set with reliabilities $>50 \%$ and genotypes. A GWAS analysis was also computed on this data set and compared with the GWAS for PEA rate.

\section{Statistical Analyses}

Variance components were estimated for data sets 1 through 4 using the AIREMLf90 program (Misztal et al., 2014). The trait analyzed in data sets 1 and 3 was FCR, and the trait analyzed in data sets 2 and 4 was PEA rate. Data sets 1 through 3 were analyzed using a single-trait animal model and data set 4 was analyzed using a multitrait animal model, with the 3 parities assumed to be different traits. In addition to the random additive genetic effect of the cow calving and service sire for the first insemination, all models included the effect of insemination month and herd-year-season as fixed effects. All known parents and grandparents of cows with records were included to construct the relationship matrix among cows (Table 2). For these data sets, 2 genetic groups were defined for animals with unlisted parents, one for males and one for females. Relationships among service sires were not included in the analysis models. Two seasons were defined for each herd-year beginning in April and October of each year.

Heritability was defined as the ratio of the additive genetic variance to the sum of additive genetic, service sire, and random residual variances. Genetic and environmental correlations among the parities were computed for data set 4. Genetic correlations were the correlations among the additive genetic effects, and environmental correlations were the correlations among the residual effects. The AIREMLf90 program also computed solutions for all effects included in the analysis model as well as standard errors for all variance components and the heritabilities and correlations.

Data set 5 was analyzed using a single-trait animal model with all 3 parities considered the same trait, as described by Weller and Ezra (1997). This model included a random permanent environmental effect in addition to the additive genetic effect common to all 3 parities. The assumed ratios of variance between the residual and the additive genetic and permanent environmental effects were both 9 based on the results from the analysis of data set 4 . Variances of PEA rate were lower in first and second parities due to lower mean PEA rates. Therefore, first- and second-parity records were each multiplied by a factor greater than unity to obtain equal phenotypic variances for all 3 parities. The modified records were then adjusted for the mean effects of parity and insemination month by subtracting the 
means of the parity-insemination month classes from each record. In addition to the additive genetic and permanent environmental effects, the model included a herd-year-season effect as described previously, a parity $\times$ herd type effect, and a genetic group effect. Two herd types were defined: Moshav (family farms) and Kibbutz (communal herds). Although the records were preadjusted for parity effects, a residual effect could remain after accounting for all the effects included in the model.

In the analysis of data set 5, 84 groups were defined based on the sex of the animal with unknown parents, which parent was unknown, and the birth year. In addition, separate groups were defined for sire of cows of breeds other than Holstein. Although only a very small fraction of the cows were sired by bulls of other breeds, these bulls were a significant fraction of the total number of bulls and an even larger fraction of the bulls with unknown parents. Details of the analysis model and the variance components used for the analysis of data set 6 are given in Weller and Ezra (2004). A total of 80 groups were defined based on the same criteria used for the analysis of data set 5 .

The overall genetic trend for PEA was computed as the regression of the cows' breeding values on their birth dates for all cows born since January 1, 1983. Yearly means of first-parity PEA rate and the breeding values of cows by birth year, relative to cows born in 2010, were also computed. Reliabilities of the breeding values of all animals included in the analyses of data sets 5 and 6 were estimated using the method of Misztal and Wiggans (1988). There were 1,701 sires with reliabilities $>0.5$ for PEA rate. Correlations were computed between the breeding values for PEA rate for these sires and the current Israel breeding index, PD16, and 11 economic traits analyzed in Israel. Breeding values for these traits were computed as described previously (Settar and Weller, 1999; Weller and Ezra, 2004, 2016; Weller et al., 2006).

Data set 7 was analyzed using the MTC REML program (Misztal, 1994) instead of AIREMLf90 due to computing limitations in the joint analysis of 10 traits. This program requires that records can be included only from animals with valid records for all traits included in the analysis and does not compute standard errors of the estimates. As in the previous variance component analyses, in addition to the random additive genetic effect of the cow calving, the model included the fixed effect of herd-year-season. All known parents and grandparents of cows with records were included to construct the relationship matrix among cows, and 2 genetic groups were defined for animals with unlisted parents, one for males and one for females.
The vector of expected genetic changes over $10 \mathrm{yr}$ $(\boldsymbol{\Phi})$ based on the genetic and residual variance components from the analysis of data set 7 was computed using the following equation (Weller, 1994):

$$
\mathbf{\Phi}=\imath \mathbf{b G} /\left(\mathbf{b}^{\prime} \mathbf{P b}\right)^{0.5}
$$

where $i=$ the selection intensity; $\mathbf{b}=$ the vector of breeding index coefficients; $\mathbf{G}=$ the genetic variance matrix; and $\mathbf{P}=$ the phenotypic variance matrix, computed as the sum of the genetic and residual variance matrices. The index coefficients for the Israeli breeding index are given in Table 3 . The selection intensity was set to 3 , which roughly corresponds to the cumulative selection intensity over the 4 paths of selection obtained after $10 \mathrm{yr}$ in an advanced breeding program (Weller, 1994). The contribution of each $j$ trait to the total selection index $\left(c_{j}\right)$ was computed as

$$
c_{j}=\frac{a b s\left(b_{j} g_{j}\right)}{\sum_{j=1}^{J} a b s\left(b_{j} g_{j}\right)},
$$

where $b_{j}=$ the index coefficient for trait $j ; g_{j}=$ the genetic standard deviation for trait $j$; and $a b s=$ absolute value. In addition to the current vector of index weights, expected genetic gains were computed with an alternative index, with zero coefficient for CS and the index coefficient for PEA equal to 20, compared with the coefficient of 26 used in PD16 for CS. A lower coefficient was used to account for the fact that the standard deviation of PEA is higher.

\section{GWAS}

A total of 1,749 Israeli Holstein bulls were genotyped. Because genotyping of these sires was performed using several SNP chip platforms, we included only those markers that were genotyped in $>90 \%$ of the tested cohort. Approximately 41,000 SNP were retained. Genome-wide associations were computed for the sires' transmitting abilities ( $1 / 2$ of the breeding value) for PEA rate and CS (Tables 1 and 2; data sets 8 and 9). Of the genotyped bulls, there were 1,179 and 1,297 with genetic evaluations for PEA rate and CS with reliabilities $>50 \%$, respectively. The additive substitution effects, the coefficients of determination, and the nominal probabilities for the hypothesis of no effect were computed using PLINK software (Purcell et al., 2007). Genome-wide probabilities were estimated by generating 1 million permutations of genotype data against the genetic evaluations. Thus, the minimal genome-wide probability was $<10^{-6}$ if the substitution 
effect obtained from the actual data was greater than all of the permutation effects.

\section{RESULTS}

The distribution of the insemination interval, as given in Figure 1, was similar to previous reports (Greenham et al., 2019). Therefore, we defined PEA as occurring when the cow was reinseminated between 49 and 100 $\mathrm{d}$ after the first insemination. This interval was previously suggested to represent embryonic death in most instances (Markette et al., 1985; Humblot, 2001).

Effects of insemination month on FCR and PEA rate as computed by best linear unbiased estimate as a by-product of the REML analysis of data sets 1 and 2 are shown in Figure 2. Effects were set to zero for December. Generally, the effects were similar for both traits, with major reductions in August and September. Thus, FCR and PEA have common phenotypic characteristics.

Estimates of variance components from the REML analyses of data sets 1 through 4 and the heritabilities are given in Table 4. First-parity heritabilities were 3.0\% for FCR from first insemination but $7.7 \%$ for PEA. For FCR with PEA deleted from the analysis, heritability for FCR decreased to $2.6 \%$. In the multitrait analysis of parities 1 through 3 for PEA, heritabilities ranged from $8.9 \%$ in first parity to $10.4 \%$ in second parity, but differences among the parities were not significant. The variance components for the service sire were 8.6 and 10.1 for the 2 analyses of conception rate but $\leq 3.5$ for all the PEA analyses.

The genetic and environmental correlations among the 3 parities for the data set 4 analysis are given in Table 5. All genetic correlations were $>0.9$, whereas all environmental correlations were $<0.12$. Thus, multiparity analysis by the single-trait animal model is justified with the variance ratios given in the Materials and Methods section.

Mean phenotypic and breeding values of non-PEA rate for first-parity cows by birth year are given in Figure 3 . The regression of the breeding value for nonPEA rate on the cows' birth year was $0.083 \% / y r ~(P<$ 0.001 ), a decrease of close to $0.1 \% / \mathrm{yr}$. Although the overall regression of breeding value was positive for non-PEA rate, PEA rate increased until 1994 and then decreased beginning in 2002. These changes correspond to changes in the Israeli breeding index. Until 1996, the index included only milk production traits. Somatic cell score was added in 1996, and CS was added in 2000. Conception status now accounts for $14 \%$ of the index (Table 6). A lag of approximately 2 yr between inclusion of a trait in the index and a change in the effective direction of selection is expected. The regres-

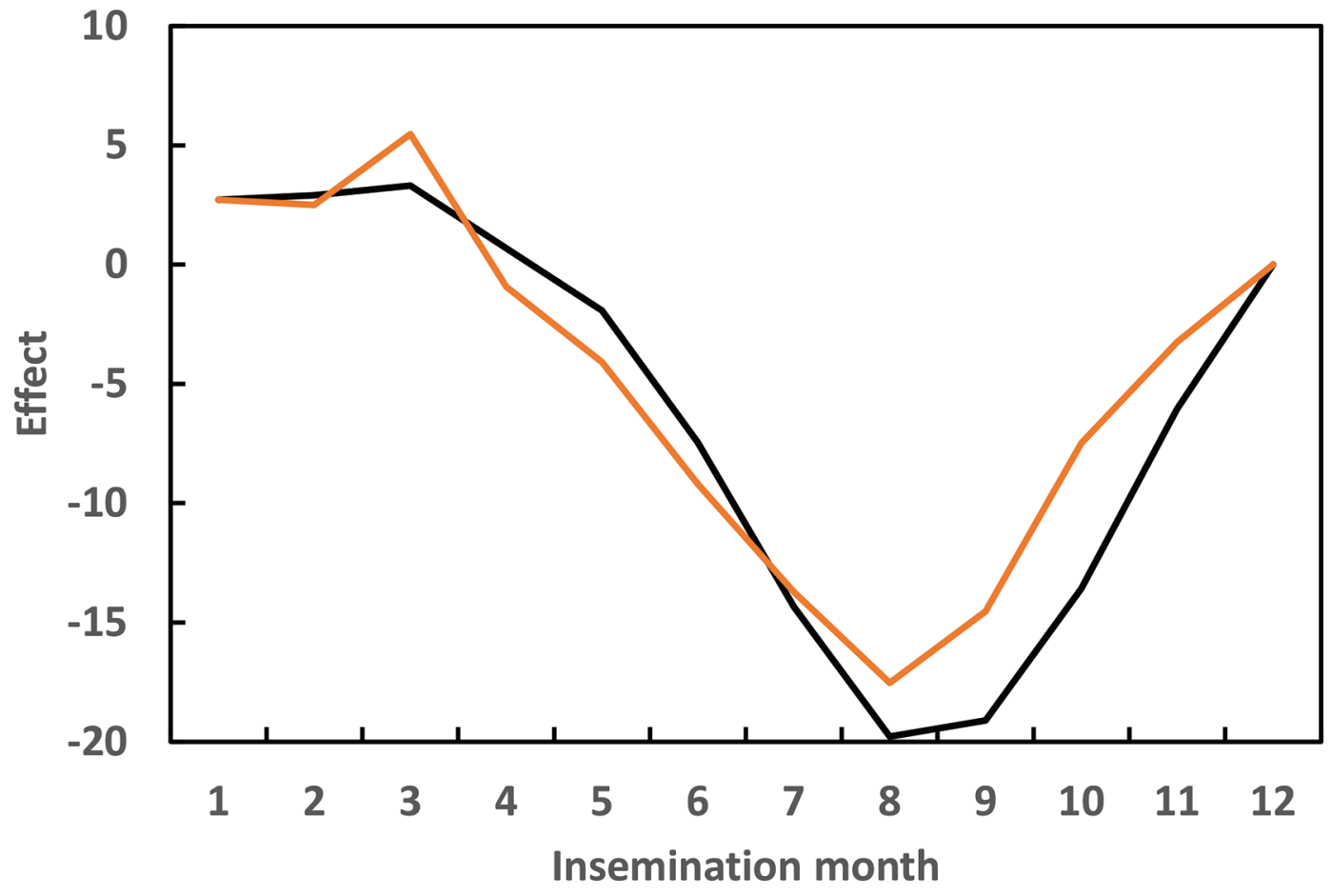

Figure 2. Effects of insemination month on conception rate (black line) and putative abortion rate (orange line). Based on valid records of cows freshening between 2007 and 2016. Score: $0=$ non-conception or putative abortion; $100=$ normal pregnancy. Effects are computed relative to December. 


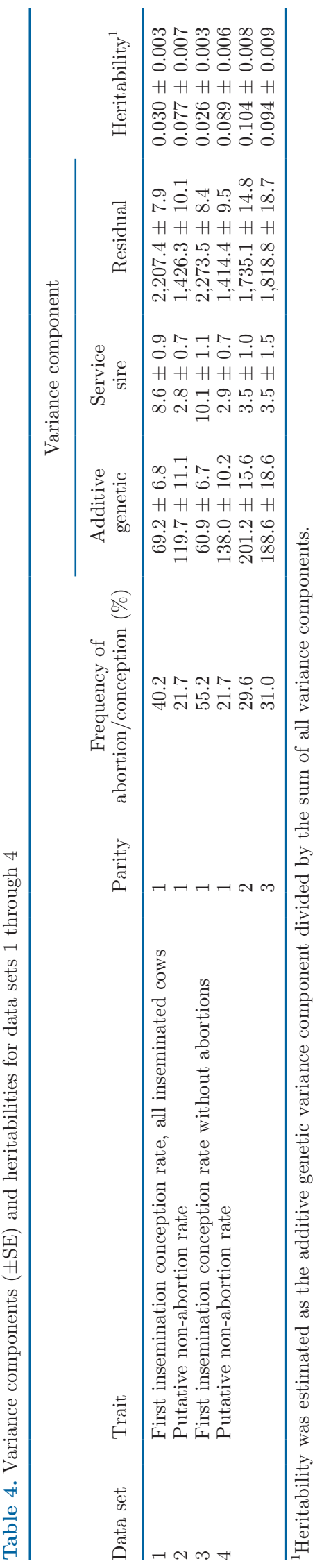

Table 5. Genetic and environmental correlations $( \pm \mathrm{SE})$ for abortion rate (data set 4$)$

\begin{tabular}{lcc}
\hline & \multicolumn{2}{c}{ Correlation $^{1}$} \\
\cline { 2 - 3 } Parities & Genetic & Environmental \\
\hline 1,2 & $0.966 \pm 0.012$ & $0.096 \pm 0.008$ \\
1,3 & $0.905 \pm 0.028$ & $0.066 \pm 0.010$ \\
2,3 & $0.963 \pm 0.017$ & $0.116 \pm 0.010$ \\
\hline
\end{tabular}

${ }^{1}$ Genetic correlations were the correlations among the additive genetic effects, and the environmental correlations were the correlations among the residual effects.

sion of breeding value on birth date for cows born since 2002 was $0.53 \% / \mathrm{yr}$ as opposed to $0.083 \%$ since 1983 . No clear trend is evident for the phenotypic means of first-parity PEA rate.

Correlations between breeding values for non-PEA rate from data set 5 and the Israeli breeding index, PD16, and the other economic traits computed for Israeli Holsteins are given in Table 6. All correlations were significantly different from zero except for the correlations with fat and protein production. The correlation with PD16 was 0.115. Thus, corresponding with the observed regression of non-PEA rate on birth date, selection for the index should have resulted in a slight decrease in PEA rate. The highest correlation was with CS (0.75), but the correlation with herd life was also 0.3. Correlations among breeding values tend to slightly underestimate the actual genetic correlations due to incomplete reliabilities of the evaluations.

First-parity heritability estimates from the analysis of data set 7 were 8.3 and $7.6 \%$ for CS and PEA, respectively. The estimate for PEA was similar to the results presented in Table 4, whereas the results for CS were higher than in previous studies (Weller and Ezra, 2004). This might be due to the truncated nature of the data; cows that were reinseminated after first insemination outside the range of 49 and $100 \mathrm{~d}$ were deleted from the data set. Genetic correlations between PEA and the traits included in PD16 are given in Table 6. All the genetic correlations were in the same directions as the correlation among the breeding values, but the genetic correlations were stronger for the production traits and for CS, which was 0.995 . That is, on this selected data set, genetically the 2 traits are almost equivalent. The environmental correlation between the 2 fertility traits was 0.96 . The discrepancy between the genetic correlation of 0.995 and the breeding value correlation of 0.75 may be due to the fact that the genetic correlation was computed on the same set of cows with valid records for both traits, whereas the breeding value correlation was based on 2 data sets with different edits.

Expected genetic changes after $10 \mathrm{yr}$ of selection with PD16 and the alternative index with a coefficient of 


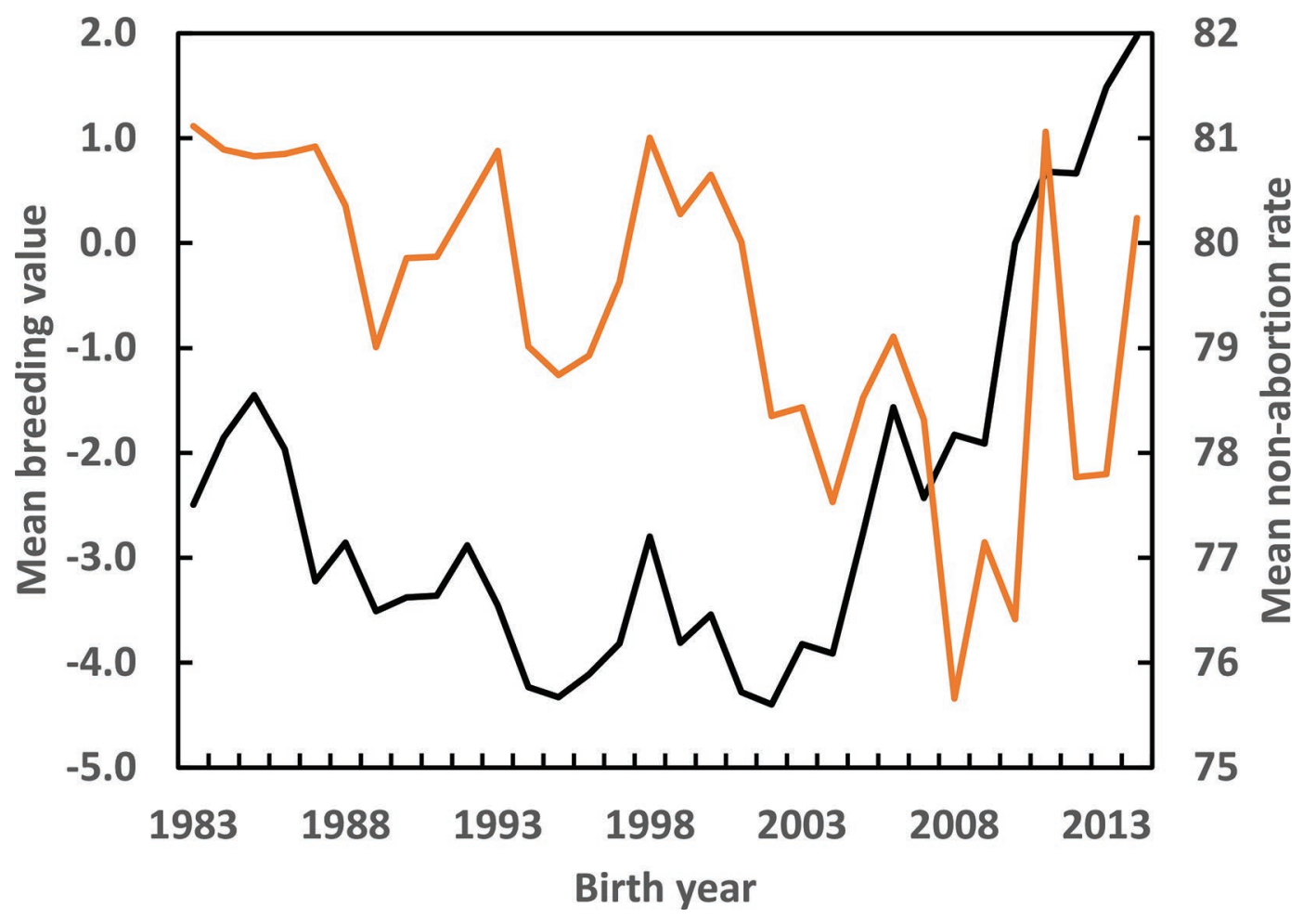

Figure 3. Mean breeding values of putative non-abortion rate (black line) and mean non-abortion rate (orange line) of first-parity cows by birth year. Score: $0=$ putative abortion; $100=$ normal pregnancy. Genetic evaluations are computed relative to cows born in 2010 .

20 for PEA are given in Table 3. The expected gain of $0.65 \%$ after $10 \mathrm{yr}$ of selection with the current index is close to the realized gain of $0.083 \% / \mathrm{yr}$ since 1983 but

Table 6. Genetic correlations between non-abortion rate and the traits included in the Israeli breeding index (PD16), and correlations between breeding values for non-abortion rate and the economic traits computed for Israeli Holsteins

\begin{tabular}{|c|c|c|c|}
\hline \multirow[b]{2}{*}{ Trait } & \multicolumn{2}{|c|}{ Correlation } & \multirow[b]{2}{*}{$\begin{array}{l}\% \text { of } \\
\text { index }{ }^{1}\end{array}$} \\
\hline & Genetic & $\begin{array}{c}\text { Breeding } \\
\text { values }\end{array}$ & \\
\hline PD16 & & $0.115^{* * *}$ & 100 \\
\hline Milk (kg) & -0.320 & $-0.077^{* *}$ & 0.00 \\
\hline Fat $(\mathrm{kg})$ & -0.225 & -0.026 & 21.20 \\
\hline Protein $(\mathrm{kg})$ & -0.333 & -0.044 & 37.32 \\
\hline $\mathrm{SCS}^{2}$ & -0.163 & $-0.196^{* * *}$ & 10.98 \\
\hline Conception status (\%) & 0.995 & $0.749^{* * *}$ & 14.38 \\
\hline Herd life $(d)$ & 0.333 & $0.296^{* * *}$ & 9.58 \\
\hline Persistency (\%) & 0.026 & $0.078^{* *}$ & 4.24 \\
\hline Dystocia, maternal $^{2}(\%)$ & -0.084 & $-0.179^{* * *}$ & 1.27 \\
\hline Stillbirth, maternal ${ }^{2}(\%)$ & -0.200 & $-0.246^{* * *}$ & 1.03 \\
\hline Dystocia, direct $^{2}(\%)$ & & $-0.105^{* * *}$ & 0.00 \\
\hline Stillbirth, direct ${ }^{2}(\%)$ & & $-0.112^{* * *}$ & 0.00 \\
\hline
\end{tabular}

${ }^{1}$ Explanation of calculation is given in the Materials and Methods section.

${ }^{2}$ Negative values are economically favorable.

${ }^{* *} P<0.01,{ }^{* * *} P<0.001$. only 0.12 of the realized gain of $0.53 \% / y r$ since 2002 . Selection based on the alternative index predicted almost equal genetic changes for most of the traits, with gains 10 to $20 \%$ greater for both fertility traits.

The Manhattan plot for the GWAS results for PEA rate are given in Figure 4, and the markers with the lowest probability values are presented in Table 7 . There were 8 markers with nominal probabilities $<10^{-11}$. All of these markers have probabilities $<10^{-6}$ after permutation analysis and correction for multiple testing. Of the 8 markers listed, the 2 markers on chromosome 7 and the 2 markers on chromosome 17 are clearly each due to a single quantitative trait locus segregating on each chromosome because the distance between the 2 markers on each chromosome is $<100,000$ base pairs. Each of these 8 markers explained between 4 and $5 \%$ of the variance for the genetic evaluations for PEA rate and $>2.5 \%$ of the variance for CS. None of these chromosomal regions were found to have significant effects on cow conception rate or daughter pregnancy rate in the analysis of the US Holstein population by the "a posteriori granddaughter design" (Weller et al., 2018).

The 30 markers with the lowest nominal probabilities for PEA rate as a function of the corresponding probabilities of these markers for CS are plotted in 


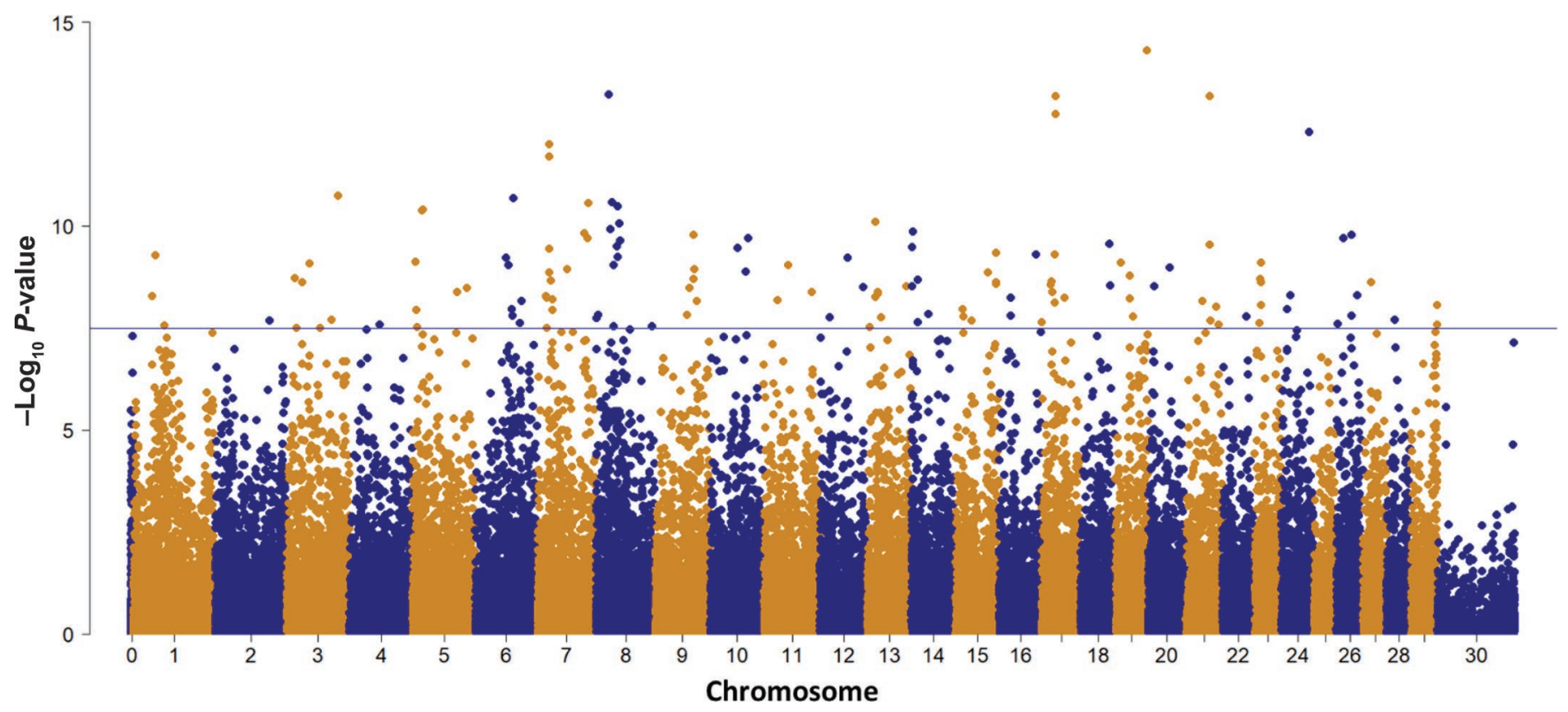

Figure 4. Genome-wide association study Manhattan plot for putative early abortion rate. Dots represent each marker. Chromosomal positions are on the x-axis, and nominal $-\log _{10} P$-values are on the y-axis. The blue line denotes the genome-wide significance threshold of 0.05 , as derived from 1 million data permutations and correction for multiple testing.

Figure 5a, and the 30 markers with the lowest nominal probabilities for CS as a function of the corresponding probabilities of these markers for PEA rate are plotted in Figure 5b. The lowest $P$-value markers for CS are not necessarily the lowest for PEA. The effects of these 30 markers on PEA and their effects on CS are plotted in Figure 6. The regression was 2.0 with a coefficient of determination of 0.97 . Thus, the substitution effect for PEA was generally twice the effect for CS. This is as expected considering that the genetic variance and heritability of PEA are greater than the corresponding statistics for CS as estimated by Weller and Ezra (2004) for parities 1 through 5.

\section{DISCUSSION}

Despite the fact that genetic factors that reduce the ability of an individual to reproduce are expected to be under intensive negative selection, reduced fertility is a common health condition in humans (de Kretser, 1997; Agarwal et al., 2015) and an important economic trait in dairy cattle. Previous studies that included measurements of progesterone and pregnancy-specific protein B levels suggested that a large portion of recorded non-conceptions in human and cattle are apparently the result of unrecognized EA (Edmonds et al., 1982; Humblot, 2001; Santos et al., 2004; Carthy et al., 2015).

Table 7. Markers with the lowest probability values for putative early abortion rate ${ }^{1}$

\begin{tabular}{|c|c|c|c|c|c|c|c|c|}
\hline \multicolumn{2}{|c|}{ Location } & SNP & \multicolumn{3}{|c|}{ Early abortion rate $^{2}$} & \multicolumn{3}{|c|}{ Conception status } \\
\hline 8 & $24,608,595$ & Hapmap41408-BTA-103152 & 1.52 & 0.047 & $6.08 \mathrm{E}-14$ & 0.83 & 0.048 & $1.34 \mathrm{E}-15$ \\
\hline 17 & $26,712,567$ & BTA-46662-no-rs & -1.95 & 0.047 & $6.60 \mathrm{E}-14$ & -1.02 & 0.045 & $1.19 \mathrm{E}-14$ \\
\hline 21 & $46,984,914$ & BTA-52458-no-rs & 1.49 & 0.047 & $6.63 \mathrm{E}-14$ & 0.60 & 0.026 & $4.51 \mathrm{E}-09$ \\
\hline 17 & $26,735,031$ & Hapmap41875-BTA-46663 & -2.23 & 0.045 & $1.81 \mathrm{E}-13$ & -1.26 & 0.050 & $3.43 \mathrm{E}-16$ \\
\hline 7 & $22,996,615$ & BTB-01398686 & 1.47 & 0.041 & $1.95 \mathrm{E}-12$ & 0.66 & 0.029 & $6.26 \mathrm{E}-10$ \\
\hline
\end{tabular}

${ }^{1}$ Markers are sorted in descending order of the probability to reject the null hypothesis of no effect on putative early abortion rate. The substitution effects and coefficients of determination are given for each marker for putative early abortion and conception status.

${ }^{2} \beta=$ the allele substitution effects in transmitting value trait units. $P=$ the nominal probability for the hypothesis of no effect. All genome-wide probabilities were $<10^{-6}$. 
In this study, we used the extensive records of the Israeli dairy cattle population to study the genetics and the genomics of PEA and to assess its association with FCR.

The effects of insemination month on FCR and PEA correspond to previous results for the effect on conception rate of Israeli Holsteins (Weller and Ron, 1992). Conception rate can be affected by the service sire and by the dam inseminated. In cattle, the service sire can effect conception rate either via the quality of semen or via genes that reduce embryo survival rate (Cole et al., 2016). With respect to EA, the effect of the sire is limited to genes affecting embryo survival rate. Although several recessive lethal genes have been detected that cause EA (Cole et al., 2016), their effects on the genetic variance of PEA rate appears to be minimal. This is not surprising, considering that the lethal allele is always quite rare. Generation of homozygotes for rare alleles is generally due to inbreeding, but inbreeding is carefully monitored in the Israeli dairy cattle population. The inbreeding from each potential mating is checked by the inseminator, and matings that result in $>3.125 \%$ inbreeding are generally rejected (Weller and Ezra, 2005).

The variance of the service sire effect on FCR is approximately 3 -fold the variance of the service sire effect on PEA rate (Table 4). This suggests that most of the service sire effect on FCR is due to semen quality; otherwise, the service sire variance component should have been of similar magnitude to the variance com-

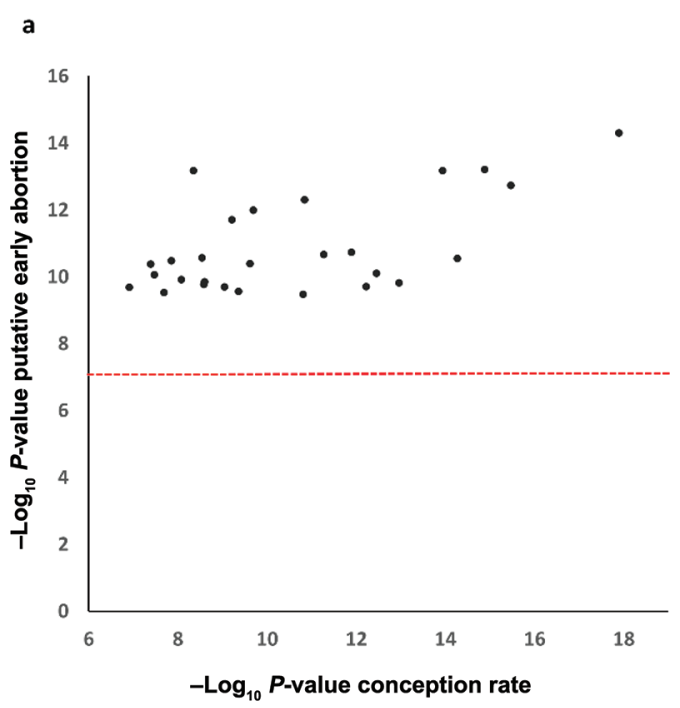

ponent for PEA. The additive genetic variance of the inseminated cow for PEA is approximately 50 times greater than the variance of the service sire, as opposed to 8 -fold for FCR. Thus, genetic control for the 2 traits is clearly different.

Only 2 previous studies attempted to estimate heritability of EA in dairy cattle, and both have notable limitations. In Bamber et al. (2009), pregnancy loss was determined by an initial pregnancy diagnosis 26 to 33 d after AI followed by determination of loss of that embryo at a subsequent diagnosis 14 to $39 \mathrm{~d}$ later, but only 3,775 cows were included in the study. Due to the relatively small sample, confidence intervals for the genetic parameters were so wide as to render the results not very informative. They found a heritability of $17 \%$, which was not significantly different from the value of approximately 7 to $10 \%$ in the current study. However, they found that the service sire variance was $16 \%$ of the total variance. This is clearly at variance with the current study and was considered difficult to explain by Bamber et al. (2009). In Carthy et al. (2015), EA was assumed to have occurred if pregnancy was determined by ultrasound examination and the embryo was deemed to be unviable by a later examination. However, ultrasound examinations were performed at various time points postpartum at the discretion of the producer. On a sample of 43,473 lactations, they found heritability of only $2 \%$ but repeatability of $66 \%$. Part of the discrepancy compared with the current study may be due to the fact that the time periods for de-

\section{b}

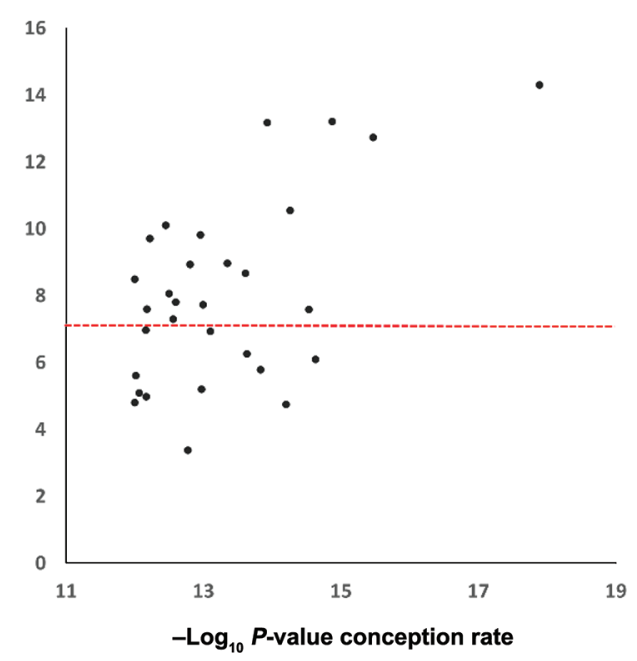

Figure 5. Comparison between the genome-wide association study results for putative early abortion rate and conception rate, computed as the inverse of the number of inseminations to conception. (a) The 30 markers with the lowest nominal probabilities for putative early abortion rate as a function of the corresponding probabilities of these markers for conception rate. (b) The 30 markers with the lowest nominal probabilities for conception rate as a function of the corresponding probabilities of these markers for putative early abortion rate. The red dashed line denotes the genome-wide significance threshold of 0.05 for putative early abortion, as derived from 1 million data permutations and after correction for multiple testing. 
termination of both pregnancy and abortion were not consistent across records. Mean embryo loss was only $8 \%$ compared with $22 \%$ for PEA in first parity in the current study.

First insemination conception rate is a quickly available trait that can be recorded on all inseminated cows for which the result of the first insemination can be determined, but it has low heritability. Putative EA has higher heritability than FCR because of the smaller residual variance with the greater genetic variance. This may be due to different genetic control of the 2 traits or different data editing. Cows for which the first insemination does not result in conception but that are not reinseminated or not reinseminated between 49 and $100 \mathrm{~d}$ after the first insemination are excluded from the analysis of PEA. The records of these excluded cows may be adding only random variation to FCR. Putative EA has a similar heritability to CS with just 2 insemination records, but PEA can be determined for only less than half of the cows with records for CS. On the other hand, there is a censoring issue with respect to CS for cows that do not conceive during the lactation. Although genetic gain for both fertility traits was greater with selection on PEA instead of CS (Table 3), this analysis included only cows with records for both traits. It is not clear how inclusion of lactations with records for CS but not PEA would affect the results.

The genetic trend for PEA rate corresponds to changes in the Israeli breeding index, as noted previously. However, the phenotypic trend is not similar to the genetic trend. Several factors can possibly explain this, including climatic variation and the fact that the phenotypic means were computed only for first-parity cows.

The GWAS results show that the markers with lowest probabilities for CS are not necessarily the lowest for PEA (Figure 5). In addition, the regression of the substitution effects of the significant PEA markers on their substitution effects for CS is approximately 2 (Figure 6). This suggests that the genetic factors that affect PEA are likely a subgroup of factors affecting CS. The markers that explain the most variance for PEA suggest possible new insights on the polygenic architecture of this trait. For instance, by investigating the genomic area flanking these markers (Table 7), we found that the marker explaining the most variance (Table 7; Figure 7a) is located within the $A B C A 9$ gene, which is found within an ATP-binding cassette (ABC) genes cluster (Figure 7a). The ABC family is the major class of primary active transporters in the placenta. The $\mathrm{ABC}$ proteins are reported to be important in efflux of xenobiotics and endogenous substrates such as lipids, sterols, and nucleotides. Recent studies provided evidence that $\mathrm{ABC}$ genes protect placental tissue by preventing accumulation of cytotoxic compounds, which is important in complicated pregnancies, such as in inflammatory or oxidative stress (Aye and Keelan, 2013). Thus, our finding of genetic variation within ABC genes clusters suggests that differences in EA predisposition might involve different sensitivity for oxidative stresses during the first trimester, mediated by $\mathrm{ABC}$ genes.

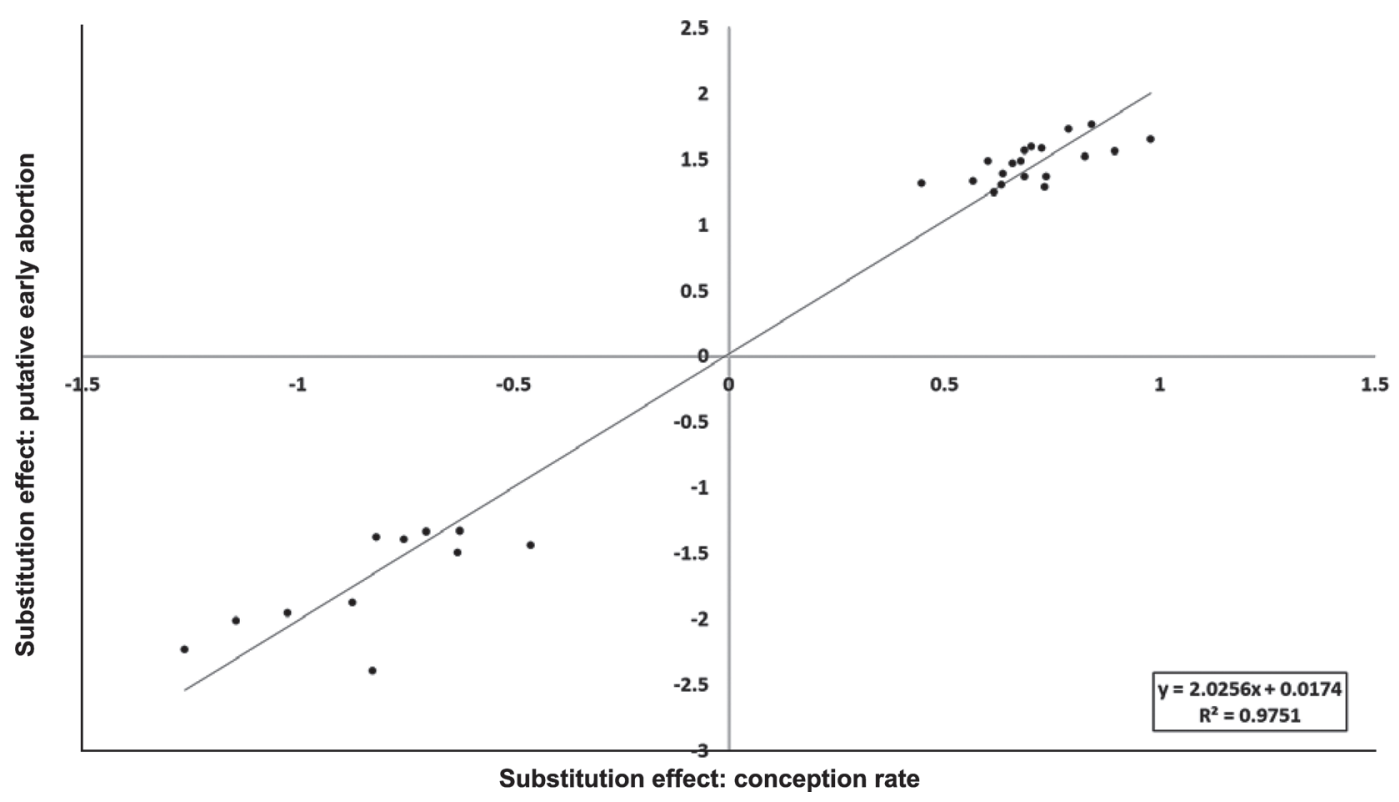

Figure 6. The substitution effects for putative early abortion rate of the 30 markers with the lowest nominal probabilities as a function of the substitution effects for the same markers for conception rate, computed as the inverse of the number of inseminations to conception. 

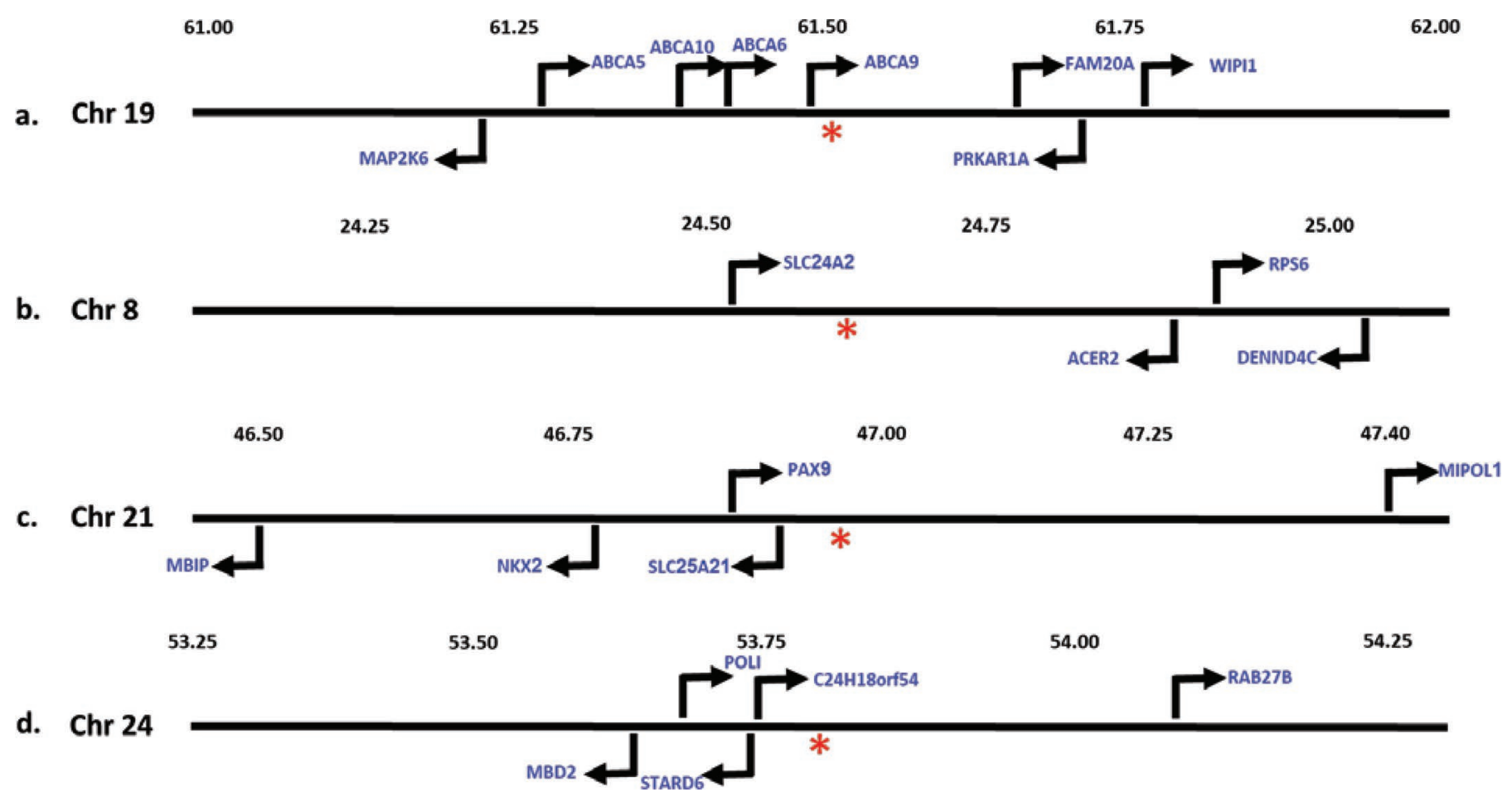

Figure 7. Schematic representation of the genomic area flanking 4 of the markers with the lowest nominal probability values (Table 7). The arrows represent the gene position and the strand orientation. The red asterisk represents the marker positions for (a) Hapmap43271-BTA-46356 located on chromosome (Chr) 19, (b) Hapmap41408-BTA-103152 located on chromosome 8, (c) BTA-52458-no-rs located on chromosome 21, and (d) BTA-58638-no-rs located on chromosome 24.

The significant marker on chromosome 21 is adjacent to the PAX9 and NKX21 genes (Figure 7c). Previous studies suggested that $P A X 9$ is required for the chondrogenic differentiation of sclerotomal cells during embryogenesis (Müller et al., 1996; Rodrigo et al., 2003) and that NKX2 is required for the embryonic development of cholinergic septohippocampal projection neurons (Magno et al., 2017). Moreover, according to PathCards, NKX21 is part of the embryo preimplementation path (Belinky et al., 2015). The fact that this marker is associated with a major effect on PEA suggests that altered predisposition for EA might be mediated by genes that regulate embryo development.

Taken together, our results support the hypothesis that long estrus interval is a true reproductive trait that affects observed CR, likely due to undetected EA. Because fertility is a major economic trait in dairy cattle (Fleming et al., 2019), our results suggest that PEA, as defined in this study, should be considered for inclusion in the commercial selection index. Shook (1989) listed the criteria that a potential trait must meet to be included in the selection objective. First, it should have an economic value. Second, the trait must have sufficiently large genetic variation in relation to its economic value and heritability. Third, the trait should be measurable at a low cost and consistently recorded. An indicator trait may be favored if it has a high genetic correlation with the economically important trait, is easier to record, has a higher heritability than the economic trait, or can be measured earlier in life (Miglior et al., 2017). The classic example of selection on an indicator trait in dairy cattle is SCS as an indicator trait for mastitis (Shook, 1989). The 2 traits have a relatively high genetic correlation, but SCS has heritability of 10 to $20 \%$ as opposed to 2 to $6 \%$ for clinical mastitis (Shook, 1989, 2006). Selection on PEA rate, as defined in the current analysis, is even more attractive as an indicator trait for female fertility in that there is no requirement to generate new data. Although heritability for CS in the current truncated data set was slightly higher than PEA, this is not the case for all previous analyses of CS (Weller and Ezra, 2004). The most recent analysis without truncation for PEA resulted in heritability of $6.3 \%$ for CS (our unpublished data). Although the 2 traits may have very similar heritability for first parity and the expected genetic gains were also similar, PEA has a definite advantage in later parities with respect to both heritability and genetic 
correlations among parities. Thus, an optimal solution may be inclusion of PEA in the index with reduced economic weight compared with CS.

\section{ACKNOWLEDGMENTS}

This research was supported by grant number 588042-5-063F from the U.S.-Israel Binational Agricultural Research and Development (BARD) Fund (Rishon LeZion, Israel) and by a grant from the Israel Dairy Board (Yehud, Israel). We thank Ignacy Misztal and Shogo Tsuruta (University of Georgia, Athens, GA) for use of the AIREMLF90 program and Michael van Straten ("Hachaklait," Caesarea Industrial Park, Israel) for useful discussions. The authors have not stated any conflicts of interest.

\section{REFERENCES}

Agarwal, A., A. Mulgund, A. Hamada, and M. R. Chyatte. 2015. A unique view on male infertility around the globe. Reprod. Biol. Endocrinol. 13:37. https://doi.org/10.1186/s12958-015-0032-1.

Aye, I. L. M. H., and J. A. Keelan. 2013. Placental ABC transporters, cellular toxicity and stress in pregnancy. Chem. Biol. Interact. 203:456-466. https://doi.org/10.1016/j.cbi.2013.03.007.

Bamber, R. L., G. E. Shook, M. C. Wiltbank, J. E. P. Santos, and P. M. Fricke. 2009. Genetic parameters for anovulation and pregnancy loss in dairy cattle. J. Dairy Sci. 92:5739-5753. https://doi .org/10.3168/jds.2009-2226.

Bauersachs, S., K. Mitko, S. E. Ulbrich, H. Blum, and E. Wolf. 2008. Transcriptome studies of bovine endometrium reveal molecular profiles characteristic for specific stages of estrous cycle and early pregnancy. Exp. Clin. Endocrinol. Diabetes 116:371-384. https:// doi.org/10.1055/s-2008-1076714.

Bauersachs, S., S. E. Ulbrich, V. Zakhartchenko, M. Minten, M. Reichenbach, H. D. Reichenbach, H. Blum, T. E. Spencer, and E. Wolf. 2009. The endometrium responds differently to cloned versus fertilized embryos. Proc. Natl. Acad. Sci. USA 106:5681-5686. https://doi.org/10.1073/pnas.0811841106.

Belinky, F., N. Nativ, G. Stelzer, S. Zimmerman, T. I. Stein, M. Safran, and D. Lancet. 2015. PathCards: Multi-source consolidation of human biological pathways. Database (Oxford) 2015:bav006. https://doi.org/10.1093/database/bav006.

Carthy, T. R., D. P. Ryan, A. M. Fitzgerald, R. D. Evans, and D. P. Berry. 2015. Genetic parameters of ovarian and uterine reproductive traits in dairy cows. J. Dairy Sci. 98:4095-4106. https://doi .org/10.3168/jds.2014-8924.

Cole, J. B., D. J. Null, and P. M. VanRaden. 2016. Phenotypic and genetic effects of recessive haplotypes on yield, longevity, and fertility. J. Dairy Sci. 99:7274-7288. https://doi.org/10.3168/jds.2015 -10777 .

de Kretser, D. M. 1997. Male infertility. Lancet 349:787-790. https:// doi.org/10.1016/s0140-6736(96)08341-9.

Edmonds, D. K., K. S. Lindsay, J. F. Miller, E. Williamson, and P. J. Wood. 1982. Early embryonic mortality in women. Fertil. Steril. 38:447-453. https://doi.org/10.1016/S0015-0282(16)46579-9.

Evans, A. C. 2003. Characteristics of ovarian follicle development in domestic animals. Reprod. Domest. Anim. 38:240-246.

Fleming, A., C. F. Baes, A. A. A. Martin, T. C. S. Chud, F. Malchiodi, L. F. Brito, and F. Miglior. 2019. Symposium review: The choice and collection of new relevant phenotypes for fertility selection. J. Dairy Sci. 102:3722-3734.

Friggens, N. C., M. Bjerring, C. Ridder, S. Højsgaard, and T. Larsen. 2008. Improved detection of reproductive status in dairy cows using milk progesterone measurements. Reprod. Domest. Anim. 43:113-121. https://doi.org/10.1111/j.1439-0531.2008.01150.x.

Greenham, T., G. Oikonomou, and D. H. Grove-White. 2019. A description of interestrus and interservice intervals and associated fertility in 16 United Kingdom dairy herds. J. Dairy Sci. 102:824832. https://doi.org/10.3168/jds.2018-14755.

Henry, L. 1965. French statistical research in natural fertility. Pages 333-350 in Public Health and Population Change. Current Research Issues. M. C. Sheps and J. C. Riley, ed. University of Pittsburgh Press, Pittsburgh, PA.

Humblot, P. 2001. Use of pregnancy specific proteins and progesterone assays to monitor pregnancy and determine the timing, frequencies and sources of embryonic mortality in ruminants. Theriogenology 56:1417-1433

Magno, L., C. Barry, C. Schmidt-Hieber, P. Theodotou, M. Häusser, and N. Kessaris. 2017. NKX2-1 is required in the embryonic septum for cholinergic system development, learning, and memory. Cell Rep. 20:1572-1584. https://doi.org/10.1016/j.celrep.2017.07 .053 .

Malhi, P. S., G. P. Adams, and J. Singh. 2005. Bovine model for the study of reproductive aging in women: Follicular, luteal, and endocrine characteristics. Biol. Reprod. 73:45-53. https://doi.org/10 .1095/biolreprod.104.038745.

Mansouri-Attia, N., O. Sandra, J. Aubert, S. Degrelle, R. E. Everts, C. Giraud-Delville, Y. Heyman, L. Galio, I. Hue, X. Yang, X. C. Tian, H. A. Lewin, and J. P. Renard. 2009. Endometrium as an early sensor of in vitro embryo manipulation technologies. Proc. Natl. Acad. Sci. USA 106:5687-5692. https://doi.org/10.1073/ pnas.0812722106.

Markette, K. L., G. E. Seidel Jr., and R. P. Elsden. 1985. Estimation of embryonic losses in bovine embryo transfer recipients from progesterone profiles and returns to estrus. Theriogenology 23:45-62. https://doi.org/10.1016/0093-691X(85)90072-X.

Miglior, F., A. Fleming, F. Malchiodi, L. F. Brito, P. Martin, and C. F. Baes. 2017. A 100-year review: Identification and genetic selection of economically important traits in dairy cattle. J. Dairy Sci 100:10251-10271. https://doi.org/10.3168/jds.2017-12968.

Misztal, I. 1994. Software packages in animal breeding. Accessed Feb. 10, 2020. http://nce.ads.uga.edu/ ignacy/numpub/mtc/.

Misztal, I., S. Tsuruta, D. A. L. Lourenco, Y. Masuda, I. Aguilar A. Legarra, and Z. Vitezica. 2014. Manual for BLUPF90 family programs. University of Georgia. Accessed Feb. 10, 2020. http:// nce.ads.uga.edu/wiki/lib/exe/fetch.php?media=blupf90_all2.pdf.

Misztal, I., and G. R. Wiggans. 1988. Approximation of prediction error variance in large-scale animal models. J. Dairy Sci. 71:27-32. https://doi.org/10.1016/S0022-0302(88)79976-2.

Müller, T. S., C. Ebensperger, A. Neubüser, H. Koseki, R. Balling, B. Christ, and J. Wilting. 1996. Expression of avian Pax1 and Pax9 is intrinsically regulated in the pharyngeal endoderm, but depends on environmental influences in the paraxial mesoderm. Dev. Biol. 178:403-417. https://doi.org/10.1006/dbio.1996.0227.

Østrup, E., P. Hyttel, and O. Østrup. 2011. Embryomaternal communication: Signalling before and during placentation in cattle and pig. Reprod. Fertil. Dev. 23:964-975. https://doi.org/10.1071/ RD11140.

Purcell, S., B. Neale, K. Todd-Brown, L. Thomas, M. A. R. Ferreira, D. Bender, J. Maller, P. Sklar, P. I. W. De Bakker, M. J. Daly, and P. C. Sham. 2007. PLINK: A tool set for whole-genome association and population-based linkage analyses. Am. J. Hum. Genet. 81:559-575. https://doi.org/10.1086/519795.

Remnant, J. G., M. J. Green, J. N. Huxley, and C. D. Hudson. 2018 Associations between dairy cow inter-service interval and probability of conception. Theriogenology 114:324-329. https://doi.org/10 .1016/j.theriogenology.2018.03.029.

Rodrigo, I., R. E. Hill, R. Balling, A. Münsterberg, and K. Imai. 2003. Pax1 and Pax9 activate Bapx1 to induce chondrogenic differentiation in the sclerotome. Development 130:473-482. https://doi.org/ 10.1242/dev.00240.

Santos, J. E. P., W. W. Thatcher, R. C. Chebel, R. L. A. Cerri, and K. N. Galvão. 2004. The effect of embryonic death rates in cattle 
on the efficacy of estrus synchronization programs. Anim. Reprod. Sci. 82-83:513-535.

Sasser, R. G. 1986. Detection of pregnancy by radioimmunoassay of a novel pregnancy-specific protein in serum of cows and a profile of serum concentrations during gestation. Biol. Reprod. 35:936-942. https://doi.org/10.1095/biolreprod35.4.936.

Schütz, E., C. Wehrhahn, M. Wanjek, R. Bortfeld, W. E. Wemheuer, J. Beck, and B. Brenig. 2016. Correction: The Holstein Friesian lethal haplotype 5 (HH5) results from a complete deletion of TBF1M and cholesterol deficiency (CDH) from an ERV-(LTR) insertion into the coding region of APOB. PLoS One 11:e0157618. https://doi.org/10.1371/journal.pone.0157618.

Settar, P., and J. I. Weller. 1999. Genetic analysis of cow survival in the Israeli dairy cattle population. J. Dairy Sci. 82:2170-2177. https://doi.org/10.3168/jds.S0022-0302(99)75461-5.

Sheps, M. C. 1965. An analysis of reproductive patterns in an American isolate. Popul. Stud. (NY) 19:65-80. https://doi.org/10.1080/ 00324728.1965.10406005.

Shook, G. E. 1989. Selection for disease resistance. J. Dairy Sci. 72:1349-1362. https://doi.org/10.3168/jds.S0022-0302(89)79242 -0 .

Shook, G. E. 2006. Major advances in determining appropriate selection goals. J. Dairy Sci. 89:1349-1361. https://doi.org/10.3168/jds .S0022-0302(06)72202-0.

VanRaden, P. M., A. H. Sanders, M. E. Tooker, R. H. Miller, H. O. Norman, M. T. Kuhn, and G. R. Wiggans. 2004. Development of a national genetic evaluation for cow fertility. J. Dairy Sci. 87:22852292. https://doi.org/10.3168/jds.S0022-0302(04)70049-1.

Weller, J. I. 1989. Genetic analysis of fertility traits in Israeli dairy cattle. J. Dairy Sci. 72:2644-2650. https://doi.org/10.3168/jds .S0022-0302(89)79405-4.

Weller, J. I. 1994. Economic Aspects of Animal Breeding. Chapman and Hall, London, UK.

Weller, J. I., D. M. Bickhart, G. R. Wiggans, M. E. Tooker, J. R. O'Connell, J. Jiang, M. Ron, and P. M. VanRaden. 2018. Determination of quantitative trait nucleotides by concordance analy- sis between quantitative trait loci and marker genotypes of US Holsteins. J. Dairy Sci. 101:9089-9107. https://doi.org/10.3168/ jds.2018-14816.

Weller, J. I., and E. Ezra. 1997. Genetic analysis of somatic cell score and female fertility of Israeli Holsteins with an individual animal model. J. Dairy Sci. 80:586-593. https://doi.org/10.3168/jds .S0022-0302(97)75974-5.

Weller, J. I., and E. Ezra. 2004. Genetic analysis of the Israeli Holstein dairy cattle population for production and nonproduction traits with a multitrait animal model. J. Dairy Sci. 87:1519-1527. https: //doi.org/10.3168/jds.S0022-0302(04)73303-2.

Weller, J. I., and E. Ezra. 2005. Analysis of inbreeding in the Israeli Holstein dairy cattle population. Interbull Bull. 33:85-87.

Weller, J. I., and E. Ezra. 2016. Genetic analysis of calving traits by the multi-trait individual animal model. J. Dairy Sci. 99:427-442. https://doi.org/10.3168/jds.2015-9768.

Weller, J. I., E. Ezra, and G. Leitner. 2006. Genetic analysis of persistency in the Israeli Holstein population by the multitrait animal model. J. Dairy Sci. 89:2738-2746. https://doi.org/10.3168/jds .S0022-0302(06)72350-5.

Weller, J. I., and M. Ron. 1992. Genetic analysis of fertility traits in Israeli Holsteins by linear and threshold models. J. Dairy Sci 75:2541-2548. https://doi.org/10.3168/jds.S0022-0302(92)78016 $-3$.

Yapura, J., R. J. Mapletoft, R. Pierson, J. Singh, J. Naile, J. P. Giesy, and G. P. Adams. 2011. A bovine model for examining the effects of an aromatase inhibitor on ovarian function in women. Fertil. Steril. 96:434-438.e3. https://doi.org/10.1016/j.fertnstert.2011.05 .038 .

\section{ORCIDS}

Moran Gershoni (i) https://orcid.org/0000-0002-2179-0799

Joel Ira Weller @ https://orcid.org/0000-0002-0668-1594 